\title{
Sustainable Production Program in the Mexican Mining Industry: Occupational Risks*
}

\section{Programa de Producción Sustentable en la Minería Mexicana: Riesgos Ocupacionales}

DOI: http://dx.doi.org/10.17981/ingecuc.11.2.2015.03

Research Article - Reception Date: April 14, 2015 - Acceptance Date: September 14, 2015

Andrea Zavala Reyna

Doctor in Science and Engineering, Department of Chemical and Biological Sciences, Universidad de Sonora. Mexico. azavala@industrial.uson.mx

Nancy Esmeralda Sánchez Duarte

Masters Student, Sustainability Postgraduate Program, Universidad de Sonora. Mexico. nancye.duarte@gmail.com

\author{
Juana Alvarado Ibarra \\ Doctor in Materials Science, Department of Polymer and Materials Research, Universidad de Sonora. Mexico. \\ jalvarado@polimeros.uson.mx
}

Luis Eduardo Velázquez Contreras

Doctor in Engineering Sciences, Department of Industrial Engineering, Universidad de Sonora. Mexico. luis_Velazquez@industrial.uson.mx

\section{Nora Elba Munguía Vega}

Doctor in Engineering Sciences, Department of Industrial Engineering, Universidad de Sonora. Mexico. nmunguia@industrial.uson.mx

To reference this paper:

A. Zavala Reyna, N. E. Sánchez Duarte, J. Alvarado Ibarra, L. E. Velázquez Contreras and N. E. Munguía Vega, "Sustainable Production Program in the Mexican Mining Industry: Occupational Risks," INGE CUC, vol. 11, no. 2, pp. 27-33, 2015. DOI: http://dx.doi.org/10.17981/ingecuc.11.2.2015.03

\begin{abstract}
Speaking of mining and sustainability sounds contradictory, as the environmental impact generated by resource extraction is well known. However, there are mining companies that are working to be safe and environmentally friendly. An example of this is presented in this study aimed at identifying occupational risks generated by the activities of a smallscale gold and silver mine located in northwestern Mexico. The methodology followed was a Sustainable Production Program (SPP) based on a continuous cycle of five steps in which the tools of cleaner production and pollution prevention are adapted. As a result of this project, it was possible to implement SPP activities: training for workers, use of personal protective equipment and adequate handling of chemicals. As a conclusion, it was verified that SPP application helped this mining company move towards sustainable patterns of production.
\end{abstract}

Keywords - Small-scale Mining, Sustainable Production, Occupational Risks, Northwest of Mexico.
Resumen - Hablar de minería y sustentabilidad suena contradictorio, ya que es bien sabido el impacto ambiental que se genera por la extracción de recursos. Sin embargo, existen empresas mineras que están trabajando para ser seguras y amigables con el ambiente. Un ejemplo de lo anterior se presenta en este estudio, cuyo objetivo fue identificar los riesgos ocupacionales generados por las actividades de una pequeña mina de oro y plata ubicada en el noroeste de México. La metodología que se siguió fue un Programa de Producción Sustentable (PPS), basado en un ciclo continuo de cinco pasos, en el cual se adaptan las herramientas de producción más limpias y prevención de la contaminación. Como resultado de este proyecto, se logró implementar el PPS en actividades de: capacitación a los trabajadores, uso de equipo de protección personal y manejo de sustancias químicas. A manera de conclusión, se establece que la aplicación del PPS coadyuva a transitar hacia patrones sustentables de producción.

Palabras claves - Pequeña Minería, Producción Sustentable, Riesgos Ocupacionales, Noroeste de México.

"Research article derived from the research project: "Producción Sustentable en la Minería Sonorense". Funded by Cuerpo Académico de Ingeniería Sustentable and the CONACyT scholarship. Starting date: January, 2013. Compleition date: December, 2014. 


\section{INTRODUCTION}

\section{A. Occupational Risks in the Mining Industry}

Mining industry has an important impact in global, national, and local economies since it has excellent profit levels and promotes local productive development [1]; moreover, during mineral extraction processes, a large investment is devoted to build adequate roads, hospitals, schools, and more, thus, helping the community through employment and the fulfillment of infrastructure needs [2].

According to data from [3], Mexico stands out for gold and silver production; it is eighth and second, respectively, in the mineral-producing world. In [4], a classification of Mexican mines is outlined; according to size, they are divided into small-, medium-, and large-scale mines. Nonetheless, regardless of their size, mining is considered as a high risk activity [5] because a considerable hazard to the health and integrity of miners (e.g. collapse, falls, noise, fire, explosion, pressure, heat, humidity, and other physical risks) is likely to take place [6].

Likewise, mining also generates chemical hazards due to silica (silicon dioxide), coal powder, and asbestos exposure, as well as to heavy metals like lead, cadmium, and others [5], [7], [8]; in a mine, workers are also liable to biological risks such as malaria, dengue, and leptospirosis, among others, depending on the mine location [9]. Other risks are related to bodily postures or ergonomic; they range from traumas as a result of physical effort to a permanent harm derived from heavy loads [6]. Miners are also exposed to psychosocial risks like drug and alcohol abuse [9]. Inherent results to the occupational risks aforementioned are respiratory and cardiovascular diseases, and cancer, among others [10], [11], [12].

Negative effects derived from mining are well known and documented; they are produced during the extraction of the mineral. Fig. 1 illustrates the extraction process from the mine studied: Virgen del Carmen Mine. As a consequence of mining, the application of tools inducing to a more sustainable approach is recommended, this includes being more efficient and having cleaner and safer operations that benefit neighboring communities and profit generation through practices that foster miners' well-being and the environment's protection, of course [13], [14].

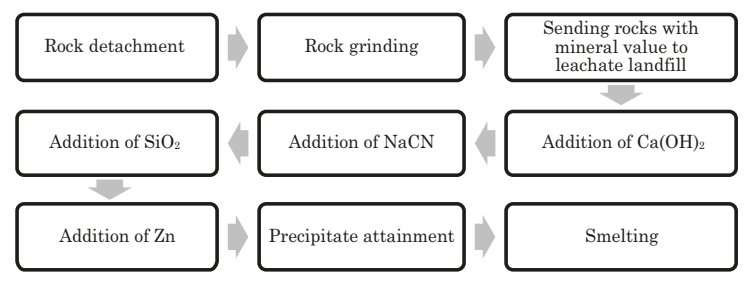

Fig.1. Gold and Silver Extraction Process in the Mine Virgen del Carmen.

Source: Author

\section{B. Cleaner Production in the Mining Industry}

Cleaner production is a tool conceived to prevent, reduce, and/or eliminate extraction process risks of mines [15]. However, to date, there is a limited set of guidelines for sustainable practices regarding mining operations; besides, these practices may have complications if applied for mining since a large amount of frameworks and indicators may be interpreted differently [13]. In accordance with [16], before introducing tools like cleaner production, they should be defined for the mining industry.

Furthermore, in [14] it is mentioned that cleaner production in the mining context refers to the organization and management aiming at minimizing or reducing problems derived from mineral extraction processes. Reinforcing this idea, [17] suggests that a mine that includes within their operations tools such as cleaner production belongs to a higher development category where efficient management techniques are implemented in order to control health hazards while allowing the reduction of occupational risks.

In [2], a list with six recommendations to be applied at any mine is put forward, this with the objective of facilitating sustainable production processes; these are: 1) Planning enhancement, 2) Enhancement of environmental management, 3) Implementation of clean technology, 4) Increasing the participation of the people involved in the process, 5) Creation of associations, and 6) Improve training of personnel. Despite some legislative, economic, and technology obstacles, the implementation of these tools is already bearing fruit as great benefits have been observed after their application.

The benefits from a sustainable operation in the mining sector are: 1) Reduction in labor and health costs by providing a suitable and safe workplace; 2) Cutting costs through the execution of cleaner production and innovation elements; 3) Easier access to financial loans, insurance companies, preferential loans, and insurance rates; 4) Reduction of closure and post-closure costs; 5) Influence of best practices; 6) Increased value of goodwill in the balance sheet, and 7) Market advantages for socially responsible enterprises [18]. Additionally, benefits like an improved corporate image, furtherance of social responsibility management, and a better relationship with the groups of interest [19].

\section{Methodology}

The methodological approach used in this research was a Sustainable Production Program (SPP) [20], which is presented in Fig. 2. This program relates economic, social, and environmental aspects; uttermost, SPP adapts cleaner production and pollution prevention tools and bases its procedures on a continuous enhancement cycle that identifies opportunity 
areas to contribute with improvement ideas. The aim is to prevent and/or reduce, from the origin, risks and severe impacts in the process, operation or activities, as well as with workers, the environment, and in general, the society.

This program comprises five stages: the first consists of a written commitment for the SPP inclusion consented by the company's senior management; in the signed commitment, directives agree on preventing, reducing and/or eliminating health and environmental risks. The second stage comprises the preparation of teamwork, diagnosis or assessment, goal and objective statement, and sustainability options proposal to, in the end, elaborate a sustainable service program. In the third stage, the selected alternatives are implemented and monitored by the team through efficiency and sustainability standards. The fourth stage is designed to assess sustainability indicators so as to determine if the data obtained agrees with the program's goals and objectives. The last stage determines which features worked in the proper manner or, if on the contrary, they need a modification.

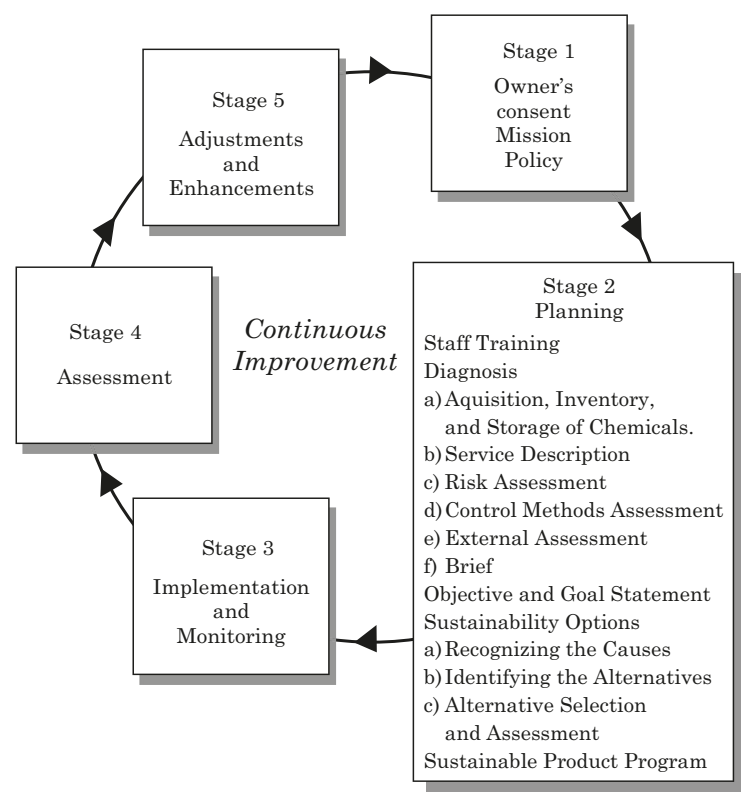

Fig. 2. Sustainable Product Program Scheme.

$$
\text { Source: Author }
$$

The SPP was executed in the Virgen del Carmen Mine, which is a 2-year-old open-pit gold and silver mine located in the municipality of Divisaderos, Sonora, México. This mine was conveniently selected as the senior management showed great interest in adopting the program. The mine's facilities are distributed in a 16.23-acre land. The human resource consists of the president, fifteen workers, a cook, and two office clerks. The variables to analyze were the mine's workers and the environmental factors.
To identify chemical hazards, the information from the Material Safety Data Sheet (MSDS) was applied to manipulate the substances used to extract gold and silver in the mine. This sheet indicates the potential risks and correct handling of the different chemical substances. Regarding physical risks during extreme temperatures periods, in the hottest months of this region (July and August), permanent measurements were taken to assess the risks for high temperature exposure. This was carried through with a TM001 Honeywell environmental thermometer with Celsius $\left({ }^{\circ} \mathrm{C}\right)$ and Fahrenheit $\left({ }^{\circ} \mathrm{F}\right)$ readings. These readings were compared to the data provided by the National Water Commission [21]. Now, concerning ergonomic risks, the OWAS (Ovako Working Analysis System) method was applied to identify the ergonomic risks miners have due to incorrect positions during work. Finally, to assess psychosocial risks, Karasek's DemandControl Model of job stress was applied. The results from this questionnaire were compared to the applicable regulations.

\section{III.RESULTS}

In this section, the results obtained with the SPP application for each stage are presented.

\section{A. Senior Management Consent}

To demonstrate the company's commitment on preventing, reducing, and/or eliminating occupational risks in the mine, a mission and a policy were established with this purpose and they were disclosed to all the staff in the mine.

\section{B. Planning}

To start the planning stage, a team was set up to make decisions derived from the SPP. This team was comprised of the president of the mine, a worker, and an external advisor.

\section{Diagnosis: Acquisition, Inventory, and Storage of Chemical Products}

From the assessment, it was established that the mine has an inventory record of chemical substances; nonetheless, storage lacks standard procedures from the Mexican regulations in force, especially the NOM-005-STPS-1998 which establishes the "Safety and hygiene conditions in the workplace for the handling, transportation, and storage of hazardous chemical substances" and the NOM-018STPS-2000 which refers to the "System of identification and communication of chemical hazards and risks in the workplace". 


\section{Occupational Risk Identification}

For occupational risk identification, the extraction process in the mine was described. Results are shown in Table I.

Table I. Occupational Risk Identifcation

\begin{tabular}{|c|c|c|}
\hline ACTIVITY & RISK & $\begin{array}{l}\text { OCCUPATIONAL } \\
\text { RISK }\end{array}$ \\
\hline $\begin{array}{l}\text { Rock } \\
\text { detachment } \\
\text { and removal } \\
\text { with } \\
\text { machinery }\end{array}$ & $\begin{array}{l}\text { Noise exposure } \\
\text { Extreme } \\
\text { temperatures } \\
\text { Falls, cuts, and } \\
\text { scratches }\end{array}$ & $\begin{array}{l}\text { Physical } \\
\text { Physical } \\
\text { Other }\end{array}$ \\
\hline $\begin{array}{l}\text { Loading the } \\
\text { truck with } \\
\text { grinded } \\
\text { material }\end{array}$ & $\begin{array}{l}\text { Noise exposure } \\
\text { Extreme } \\
\text { temperatures } \\
\text { Falls, cuts, and } \\
\text { scratches }\end{array}$ & $\begin{array}{l}\text { Physical } \\
\text { Physical } \\
\text { Other }\end{array}$ \\
\hline $\begin{array}{l}\text { Calcium } \\
\text { hydroxide } \\
\text { addition }\end{array}$ & $\begin{array}{l}\text { Chemical substance } \\
\text { exposure }\end{array}$ & Chemical \\
\hline $\begin{array}{l}\text { Preparation } \\
\text { of } \\
\text { mineralized } \\
\text { rock levels }\end{array}$ & $\begin{array}{l}\text { Noise exposure } \\
\text { Extreme } \\
\text { temperatures } \\
\text { Falls, cuts, and } \\
\text { scratches }\end{array}$ & $\begin{array}{l}\text { Physical } \\
\text { Physical } \\
\text { Other }\end{array}$ \\
\hline $\begin{array}{l}\text { Sodium } \\
\text { cyanide } \\
\text { addition } \\
\text { once there is } \\
\text { an adequate } \\
\text { pH }\end{array}$ & $\begin{array}{l}\text { Chemical substance } \\
\text { exposure } \\
\text { Uncomfortable } \\
\text { bodily positions }\end{array}$ & $\begin{array}{l}\text { Chemical } \\
\text { Ergonomic }\end{array}$ \\
\hline $\begin{array}{l}\text { Beginning } \\
\text { of irrigation }\end{array}$ & $\begin{array}{l}\text { Chemical substance } \\
\text { exposure }\end{array}$ & Chemical \\
\hline $\begin{array}{l}\text { Irrigation } \\
\text { hoses } \\
\text { supervision } \\
\text { to prevent } \\
\text { leakage or } \\
\text { obstruction }\end{array}$ & $\begin{array}{l}\text { Chemical substance } \\
\text { exposure } \\
\text { Extreme } \\
\text { temperatures }\end{array}$ & $\begin{array}{l}\text { Chemical } \\
\text { Physical }\end{array}$ \\
\hline $\begin{array}{l}\text { Silica } \\
\text { addition in } \\
\text { the mixing } \\
\text { machine }\end{array}$ & $\begin{array}{l}\text { Chemical substance } \\
\text { exposure }\end{array}$ & Chemical \\
\hline $\begin{array}{l}\text { Zinc } \\
\text { addition } \\
\text { with } \\
\text { dispenser }\end{array}$ & $\begin{array}{l}\text { Chemical substance } \\
\text { exposure }\end{array}$ & Chemical \\
\hline $\begin{array}{l}\text { Precipitate } \\
\text { attainment }\end{array}$ & $\begin{array}{l}\text { Chemical substance } \\
\text { exposure }\end{array}$ & Chemical \\
\hline
\end{tabular}

Source: Author

\section{E. Assessment of Risk Identification}

Table II poses the assessment results of chemical, physical, and ergonomic risks.
Table II. Assessment Results Of Occupational Risks Identified

\begin{tabular}{|l|l|}
\hline \multicolumn{1}{|c|}{ RISK } & \multicolumn{1}{c|}{ RESULT } \\
\hline $\begin{array}{l}\text { Chemical substance } \\
\text { exposure }\end{array}$ & $\begin{array}{l}\text { Information from MSDS reveals } \\
\text { potential harms for the miners } \\
\text { health. }\end{array}$ \\
\hline $\begin{array}{l}\text { Extreme } \\
\text { temperatures }\end{array}$ & $\begin{array}{l}\text { Maximum temperature of } 31.6^{\circ} \mathrm{C} \\
\text { and minimum temperature of } \\
21.9^{\circ} \mathrm{C} .\end{array}$ \\
\hline $\begin{array}{l}\text { Uncomfortable } \\
\text { bodily positions }\end{array}$ & Risk 3 bodily positions \\
\hline Stress & $\begin{array}{l}\text { Labor stress surveys show that a } \\
45 \% \text { of workers manifest low stress } \\
\text { levels, 33\% high stress levels, and } \\
22 \% \text { very high stress levels. }\end{array}$ \\
\hline $\begin{array}{l}\text { Falls, cuts, and } \\
\text { scratches }\end{array}$ & $\begin{array}{l}\text { An accident was reported during the } \\
\text { observation period. }\end{array}$ \\
\hline & Source: Author \\
\hline
\end{tabular}

\section{F. Control Methods Assessment}

The lack of a closed system for chemical use and adequate safety signs was identified; also, neither MSDSs nor a risk prevention program are available for employees. This fails to fulfill the NOM-023-STPS-2012 requirements related to "Underground and open-pit mines - Safety and health conditions at work".

\section{G. External Assessment}

A document and operating permits review was carried out: Manifestation of Environmental Impact (MEI), changes in land use, and the planning of stages where the Secretary of Environment and Natural Resources (SEMARNAT by its acronym in Spanish) acts as a grantor for the processes in the Virgen del Carmen Mine. These documents are in force and periodically checked

\section{H. Brief}

Based on the external advisor's experience and knowledge each occupational risk was weighted, including: a comprehensive vision in regard to the worker's health, magnitude terms, severity of the impact, its duration and frequency or likelihood of occurrence, whether it is related to the fulfillment of a determined regulation or if it can be controlled or influenced by the members of the sustainability team; all these depend on their relevance for the company. Hence, the statement of objectives and goals for the SPP can be established.

\section{Sustainable Production Program}

Table III puts forward the Sustainable Production Program with its corresponding objectives and goals. 
Table III. Objectives and Goals Set Up in the SpP

Objective 1. Prevent and/or reduce occupational risks produced by the handling of hazardous chemicals.

Goal 1.1. All the chemicals need to be transported safely so as to prevent any health risks.

Goal 1.2. All the chemicals in the mine must have their corresponding MSDS and a homogenous system for risk identification.

Goal 1.3. Establish an exclusive area for hazardous chemical storage.

Goal 1.4. Use technology and personal protection equipment recommended by NIOSH in every operation involving the use of hazardous chemicals.

Goal 1.5. Design and implement contingency plans.

Objective 2. Prevent and/or reduce occupational risks derived from the final disposal of hazardous materials.

Goal 2.1. Adequate treatment of solid waste generated.

Goal 2.2. Availability of an emergency pool.

Goal 2.3. Converting sprinkling irrigation systems to drip irrigation.

Source: Author

\section{J. Implementation and Monitoring}

In this section, SPP was implemented and monitored considering the team's proposals for sustainability. These alternatives are presented in Table IV, where applicable regulations and their benefits are also put forward. Resource allotment to guarantee the application of the alternatives defined during the planning stage is the objective here. Moreover, this stage describes the job, technology, and financial resources needed to accomplish each of these options. The details of resource allotment depend on the mine's managers, however, they must at least cover the necessary activities to achieve the alternatives during the required period of time.

\section{K. Assessment of the Plan}

In this section, the team checked the information collected to determine if the data obtained agreed with the program's objectives and goals. The assessment allowed verifying if there were digressions from the original plan, and if so, making decisions in order to reorient the alternatives.

Table V poses the percentage of objective and goal achievement.

Table V. Objectives, Goals and Achievement Percentage in The Implmentation

\begin{tabular}{|c|c|c|}
\hline Objective & Goal & Achievement (\%) \\
\hline $\begin{array}{l}\text { Objective } 1 . \\
\text { Prevent and/ } \\
\text { or reduce } \\
\text { occupational } \\
\text { risks produced } \\
\text { by the handling } \\
\text { of hazardous } \\
\text { chemicals. }\end{array}$ & $\begin{array}{l}\text { Goal 1.1. All the } \\
\text { chemicals need to be } \\
\text { transported safely } \\
\text { so as to prevent } \\
\text { any contingencies } \\
\text { regarding public } \\
\text { health. } \\
\text { Goal 1.2. All the } \\
\text { chemicals in the } \\
\text { mine must have } \\
\text { their corresponding } \\
\text { MSDS. } \\
\text { Goal 1.3. Use the } \\
\text { personal protection } \\
\text { equipment } \\
\text { recommended by } \\
\text { NIOSH in every } \\
\text { operation involving } \\
\text { the use of hazardous } \\
\text { chemicals. }\end{array}$ & $\begin{array}{l}100 \% \\
100 \% \\
100 \%\end{array}$ \\
\hline $\begin{array}{l}\text { Objective } 2 . \\
\text { Prevent and/ } \\
\text { or reduce } \\
\text { occupational } \\
\text { risks derived } \\
\text { from the final } \\
\text { disposal of } \\
\text { hazardous } \\
\text { materials. }\end{array}$ & $\begin{array}{l}\text { Goal } 2.1 . \\
\text { Adequate treatment } \\
\text { of solid waste } \\
\text { generated. } \\
\text { Goal } 2.2 \text {. } \\
\text { Availability of an } \\
\text { emergency pool. }\end{array}$ & $\begin{array}{l}50 \% \\
100 \%\end{array}$ \\
\hline
\end{tabular}

Source: Author

Table IV. Alternatives, Applicable Regulations and Benefits of Spp

\begin{tabular}{|c|l|l|l|}
\hline Alternative & Description & Applicable Regulation & Benefits \\
\hline A1 & Training program for workers & NOM- 005- STPS-1998 & Development of skills \\
\hline A2 & Chemical transportation & NOM-003-SCT2-2000 & Reduction of pollution \\
\hline A3 & MSDS for every chemical & NOM-018-STPS-2000 & Awareness increase \\
\hline A4 & Storage of chemicals & NOM-05-STPS-2014 & Leakage/Spilling and accident prevention \\
\hline A5 & Clean and safe workplace & NOM- 002-STPS-2000 & Accident prevention \\
\hline A6 & Contingency plan & NOM- 002-STPS-2000 & Accident prevention \\
\hline A7 & Solid waste treatment & NOM-052-SEMARNAT-2005 & Reduction of pollution \\
\hline A8 & Emergency pool & NOM-023-STPS-2012 & Pollution prevention \\
\hline A9 & Drip irrigation system & NOM-023-STPS-2012 & Pollution prevention \\
\hline
\end{tabular}

Source: Author 


\section{Discussion}

Mining involves health risks derived from the substances used during the extraction process [22]; additionally, it entails risk factors like stress, ergonomic problems, extreme temperatures, falls, cuts, and bruises, as evidenced in this project.

Obviously, the implementation of measures aimed at reducing pollution and occupational risk problems have positive impact regarding mining productivity in Mexico, since a permanent work in enhancement programs contributes towards a sustainable production [23, 24]. This study agrees on this because through the application of the SPP numerous benefits were obtained by reducing workers' occupational risks.

There are still limited guidelines in terms of the sustainable practices applied in the mining industry [13]. This project confirms that with a prudent execution of a design methodology, regarding extraction in Virgen del Carmen Mine, these practices can be achieved successfully, however, a permanent improvement of the processes is mandatory for a progressive enhancement.

It is strongly recommended a constant training of the staff so as to create awareness in the workers about every task they perform and their related risks. Likewise, monitoring of the alternatives implemented is also required in order to identify any possible malfunction and perform the necessary corrections or changes.

\section{Conclusions}

Mining activities inevitably lead to occupational risks that may affect the health of workers and the neighboring communities. For this reason, a Sustainable Production program needs to be implemented. As described in this paper, a SPP by itself is not enough to guarantee sustainability in this industry; nevertheless, it certainly increases the likelihood of developing strategies that, besides assuring a longterm economic growth, include the betterment of the environment and labor conditions. This is ensured by the inclusion of cleaner production techniques in their activities aimed at preventing, reducing, and/ or eliminating occupational risks generated by their operations.

However, and despite the implementation of this program was only executed in one mine, the success of this model largely depends on not only the commitment of the mine's owners and workers but also of the government, suppliers, mining associations, education institutions, research centers, and the society in general.

\section{References}

[1] J. Oyarzún, "Minería, desarrollo y ambiente: una perspectiva histórica," 2009. [Online]. Available: http:// www.aulados.net/Ciencia_Sociedad/Mineria_Desarrollo_Ambiente/Mineria_Desarrollo_Ambiente.pdf.

[2] G. Hilson and B. Murck, "Sustainable development in the mining industry: clarifying the corporate perspective," Resour. Policy, vol. 26, pp. 227-238, 2000.

[3] INEGI, "Actividades económicas secundarias: Minería," 2010. [Online]. Available: http://www.inegi.org.mx/.

[4] F. González-Sánchez and A. Camprubí, "Boletín de la Sociedad Geológica Mexicana,” vol. 62, no. 1, pp. 101$108,2010$.

[5] D. Meza, R. Maier, M. De la O, A. Gómez, A. Moreno, J. Rivera, A. Campillo, C. Grandlic, R. Anaya, and J. Palafox, "The impact of unconfined mine tailings in residential areas from a mining town in a semi-arid environment: Nacozari, Sonora, Mexico," Chemosph. 77, pp. 140-147, 2009. DOI: 10.1016 / j.chemosphere.2009.04.068

[6] J. Oyarzún and R. Oyarzun, "Minería sostenible: Prin cipios y prácticas," 2011. [Online]. Available: http:// eprints.ucm.es/13264/1/Libro_Mineria_Sostenible.pdf.

[7] Y. R. Ramos Arroyo, R. M. Prol Ledesma, and C. D. Siebe Grabach, "Características geológicas y mineralógicas e historia de extracción del Distrito de Guanajuato, México. Posibles escenarios geoquímicos para los residuos mineros," Rev. Mex. Ciencias Geológicas, vol. 21, no. 2, pp. 268-284, 2004.

[8] D. Cain, "Sustainable development and the mineral industry," Aust. Coal Rev., vol. 32, no. 15, pp. 13-15, 2000

[9] A. M. Donoghue, "Occupational health hazards in mi ning: an overview,” Occup. Med. (Lond)., vol. 54, no. 5, pp. 283-9, Aug. 2004. DOI : 10.1093/occmed/kqh072

[10] D. Gallardo-Martínez, I. Cabrera-Díaz, N. BrugueraAmaran, and F. Madrazo-Escalona, "Evaluación de impactos ambientales provocados por la actividad minera en la localidad de Santa Lucía, Pinar del Río.," Rev. Av., vol. 15 , no. 1, pp. 94-108, 2013.

[11] L. Carrizales, I. Razo, J. I. Téllez-Hernández, R. TorresNerio, A. Torres, L. E. Batres, A.-C. Cubillas, and F. Díaz-Barriga, "Exposure to arsenic and lead of children living near a copper-smelter in San Luis Potosi, Mexico: Importance of soil contamination for exposure of children," Environ. Res., vol. 101, no. 1, pp. 1-10, May 2006. DOI: 10.1016/j.envres.2005.07.010.

[12] L. Yáñez, E. García-Nieto, E. Rojas, L. Carrizales, J. Mejía, J. Calderón, I. Razo, and F. Díaz-Barriga, "DNA damage in blood cells from children exposed to arsenic and lead in a mining area," Environ. Res., vol. 93, no. 3, pp. 231-40, Nov. 2003. DOI: 10.1016/j.envres.2003.07.005

[13] J. L. Rosado, D. Ronquillo, K. Kordas, O. Rojas, J. Alatorre, P. Lopez, G. Garcia-Vargas, M. Del Carmen Caamaño, M. E. Cebrián, and R. J. Stoltzfus, "Arsenic exposure and cognitive performance in Mexican schoolchildren," Environ. Health Perspect., vol. 115, no. 9, pp. 1371-5, Sep. 2007. DOI: 10.1289/ehp.9961

[14] D. Laurence, "Establishing a sustainable mining operation: an overview," J. Clean. Prod., vol. 19, no. 2-3, pp. 278-284, Jan. 2011. DOI: 10.1016/j.jclepro.2010.08.019

[15] S. A. Moreno Zazueta And J. M. Rodríguez Zavala, "Sustentabilidad Y Mineria ¿Es Esto Posible?," Epistemus, Vol. 1, No. 4, Pp. 76-81, 2008.

[16] G. Hilson, "Pollution prevention and cleaner production in the mining industry: an analysis of current issues," $J$. Clean. Prod., vol. 8, no. 2, pp. 119-126, Apr. 2000.DOI: 10.1016/S0959-6526(99)00320-0

[17] G. Hilson, "Defining 'cleaner production' and 'pollution prevention' in the mining context," Miner. Eng., vol. 16, no. 4, pp. 305-321, Apr. 2003.DOI: 10.1016/S08926875(03)00012-8 
[18] G. Hilson, "Barriers to implementing cleaner technologies and cleaner production (CP) practices in the mining industry: A case study of the Americas," $M i$ ner. Eng., vol. 13, no. 7, pp. 699-717, Jul. 2000. DOI: $10.1016 / \mathrm{S} 0892-6875(00) 00055-8$

[19] A. Azapagic, "Developing a framework for sustainable development indicators for the mining and minerals industry," J. Clean. Prod., vol. 12, no. 6, pp. 639-662, Aug. 2004. DOI: 10.1016/S09596526(03)00075-1

[20] Acción RSE, "Mejores prácticas de los reportes de sustentabilidad en Chile," 2010. [Online]. Available: http://www.mapeo-rse.info/sites/default/files/Mejores_practicas_de_los_Reportes_de.pdf.
[21] A. Zavala, R. Moure-Eraso, N. Munguía, and L. Velázquez, "A Sustainable Services System in the Automotive Refinishing Industry," in New Trends and Developments in Automotive Industry, M. Chiaberge, Ed. InTech, 2011, pp. 89-107. DOI: 10.5772/1821

[22] “Comisión Nacional del Agua." [Online]. Available: http:// www.conagua.gob.mx/. [Accessed: 01-Jul-2014].

[23] E. R. Gazdag and E. Sipter, "Geochemical background in heavy metals and human health risk assessment at an ore mine site, Gyöngyösoroszi (North Hungary)," Carpathian J. Earth Environ. Sci., vol. 3, no. 2, pp. 83-92, 2008.

[24] R. G. Eggert, "Sustainable Development and the Mineral Industry," in Sustainable Development and the Future of Mineral Investment, France: Division of Technology, Industry and Economics, 2000. 